from the effect of dietary consumption of salt. Given the current state of knowledge, it might be prudent for men with asthma refractory to other treatments to avoid a high sodium intake.

\section{ALAN KNOX} Senior lecturer

Respiratory Medicine Unit,

City Hospital,

Nottingham NG5 1PB

1 Burney P. A diet rich in sodium may potentiate asthma. Epidemiological evidence for a new hypothesis. Chest 1991;6:143-7S.

Burney PGJ, Britton JR, Chinn S, Tattersfield AE, Platt HS, Papacosta AO, et a!. Response to inhaled histamine and 24 hour sodium excretion. $B M f 1986 ; 292: 1483-6$.

3 Pistelli R, Forastiere F, Corbo GM, Dell'Orco V, Brancato G, Agabiti N, et al. Respiratory symptoms and bronchial responsiveness are related to dietary salt intake and urinary potassium excretion in male children. Eur Respir f 1993;6:517-22.

4 Sparrow D, O'Connor GT, Rosner B, Weiss ST. Methacholine airway responsiveness and 24-hour urine excretion of sodium and potassium. Am Rev Respir Dis 1991;144:722-5.

5 Beach JR, Young CL, Dennis JH, Williams SE, Avery AJ, Walters EH, et al. A survey of airway responsiveness to methacholine and urinary sodium excretion. Thorax 1992;47:856P.
6 Javaid A, Cushley MJ, Bone MF. Effect of dietary salt on bronchial reactivity to histamine in asthma. $B M \mathcal{F} 1988 ; 297: 454$.

7 Burney PGJ, Neild JE, Twort CHC, Chinn S, Jones TD, Mitchell WD, et al. Effect of changing dietary sodium on the airway response to histamine. Thorax 1989;44:36-41.

8 Lieberman D, Heimer D. Effect of dietary sodium on the severity of bronchial asthma. Thorax 1992;47:360-2.

9 Carey OJ, Locke C, Cookson JB. Effect of alterations of dietary sodium on the severity of asthma in men. Thorax 1993;48:714-8.

10 Blaustein MP. Sodium ions, calcium ions, blood pressure regulation, and hypertension: a reassessment and a hypothesis. Am f Physiol 1977;232:C165-73.

11 Knox AJ, Ajao P, Britton JR, Tattersfield AE. Effect of sodium transport inhibitors on airway smooth muscle contractility in vitro. Clin Sci 1990;79:315-23.

12 Skoner DP, Gentile D, Evans RW. A circulating inhibitor of the platelet sodium, potassium adenosine triphosphatase (ATPase) enzyme in allergy. $₹$ Allergy Clin Immunol 1991;87:476-82.

13 Knudsen T, Bertelsen H, Johansen T. Ouabain enhancement of compound 48/80 induced histamine secretion from rat peritoneal mast cells: dependence on extracellular sodium. Pharmacol Toxicol 1992;70:412-8.

14 Romoff MS, Keusch G, Campese VM, Wang MS, Friedler RM, Weidmann P, et al. Effect of dietary salt intake on plasma catecholamines in normal subjects. $f$ Clin Endocrinol Metab 1979;48:26-31.

15 Knox AJ, Campos-Gongora H, MacDonald IA, Tattersfield AE. Modification of bronchial reactivity by physiological concentrations of plasma epinephrine. I Appl Physiol 1992;73: 1004-7.

$16 \mathrm{Ng} \mathrm{AV}$, Callister R, Johnson DG, Seals DR. Age and gender influence muscle sympathetic nerve activity at rest in healthy humans. Hypertension 1993;21:498-503.

17 Fraser CL, Samacki P. Na $\mathrm{K}^{+}$ATPase pump function in rat brain synaptosomes is different in males and females. Am F Physiol 1989;257:E284-9.

\title{
New powers of supervised discharge of mentally ill people
}

\section{The current compromise reflects the lack of consensus}

Earlier this year the secretary of state for health published the report of her official review ${ }^{2}$ of the Royal College of Psychiatrists' proposals ${ }^{3}$ for a community supervision order to maintain the treatment of mentally ill patients discharged after having been detained. This order would have ensured support for a limited group of patients, mainly people suffering from recurrent schizophrenia and manic depressive psychosis. Typically such people respond to treatment in hospital but fail to comply with a care plan, reject drug treatment, relapse, and are redetained; the whole cycle then begins again. Currently redetention requires the patient to display the symptoms of mental illness that would justify detention under section 2, 3, or 4 of the Mental Health Act 1983. The proposed community supervision order would have ensured that treatment was maintained outside hospital but would have permitted earlier compulsory return to re-establish medical treatment if necessary.

These suggestions raised various controversial legal, social, and ethical issues, and the publication of the college's report was followed by a lively national debate and Mrs Bottomley's review. Concurrently, the House of Commons health committee also inquired into the case for community supervision orders and most interested groups gave evidence to both the committee and the official review.

The health committee rejected the college's proposals for a community supervision order, giving seven specific reasons. These included a reluctance to accept the concept of consent given in advance of compulsory treatment and objections to a view of treatment centred on the use of drugs and to applying statutory controls to people who may "for all intents and purposes be well."

Other opponents to the college's proposals argued that the 1983 act already contained sufficient powers, civil rights would be infringed, lazy practice would be encouraged, patients might validly wish to refuse drugs, and ethnic groups would be vulnerable to discrimination. Some wished to encourage a wider use of guardianship.

The Department of Health's review supports more guardianship orders and as "an interim measure" suggests extending leave of absence, so that the patient could remain in the community subject to conditions imposed by a responsible medical officer for up to a year from the date when the patient is first detained (rather than six months as at present). This should meet with approval from psychiatrists. In addition, a new form of supervised discharge is recommended. This would embody the principles of care programmes and the key features of guardianship. The conditions and supervision would be focused on a key worker, who, with the responsible medical officer and others, would review. the plan if things went wrong. Recall would be voluntary or rely on the existing criteria for detention. A mental health review tribunal might institute such a discharge, and a patient would have the right to apply periodically to a tribunal to be removed from these arrangements.

The Department of Health's report also emphasises the need for better training in understanding the act, wider awareness of its code of practice, and guidance to practitioners on key considerations when potentially violent or dangerous patients are discharged.

These recommendations are a compromise solution that reflects the lack of consensus among users, carers, and professionals about tackling this difficult group of patients. ${ }^{4}$ Extended leave is helpful, but in other respects these new arrangements closely resemble guardianship orders, which have been largely ineffective. A few "revolving door patients" may be helped to survive for longer in the community, but only experience will confirm that the recommendations are enough to limit substantially the numbers who fall through the safety net.

ROBERT BLUGLASS

Professor of forensic psychiatry

University of Birmingham,

Reaside Clinic,

Birmingham B45 9BE

1 Department of Health. Legal powers on the care of mentally ill people in the community. Report of the internal review. London: Department of Health, 1993.

2 Groves T. Government wants wider legal powers for community care. BMf 1993;307:463.

3 Royal College of Psychiatrists. Community supervision orders. London: Royal College of Psychiatrists, 1993. 4 Bluglass R. Maintaining the treatment of mentally ill people in the community. BMF 1993;306:
$159-60$. 